\title{
Complementation of Mutations in Escherichia coli and Bordetella pertussis by $B$. pertussis DNA Cloned in a Broad-host-range Cosmid Vector
}

\author{
By R. M. BROWNLIE, * J. G. COOTE AND R. PARTON \\ Department of Microbiology, University of Glasgow, Alexander Stone Building, Garscube Estate, \\ Bearsden, Glasgow G61 1QH, UK
}

(Received 26 March 1986; revised 6 June 1986)

\begin{abstract}
A gene library of Bordetella pertussis DNA was constructed in Escherichia coli using the broadhost-range cosmid vector pLAFRl. The average insert size was $24.9 \mathrm{~kb}$. From 500 members of the gene library, clones were identified which complemented $\operatorname{trp} E, g \ln A$ and $\mathrm{Thr}^{-}$mutations in $E$. coli but none which complemented $\operatorname{trp} D, \operatorname{trp} C, \operatorname{trp} B, \operatorname{trp} A, \operatorname{pro} A$ or $\mathrm{Leu}^{-}$mutations. Four clones were identified which complemented $\operatorname{trp} E$ in $E$. coli. Anthranilate synthase activity was detected in a $\operatorname{trp} E$ strain only when it harboured a plasmid from one of these clones; activity was repressed when tryptophan was included in the growth medium. Two clones were identified which complemented $g \ln A$ of $E$. coli. A recombinant plasmid from one of these clones also restored some of the nitrogen acquisition functions of $g \ln G$ and $g \ln L$ in $E$. coli. Expression of several $B$. pertussis virulence-associated products (haemolysin, heat-labile toxin, adenylate cyclase, filamentous haemagglutinin, and the cell-envelope polypeptide of $M_{\mathrm{r}} 30000$ ) was not detected in 500 independent clones. However, by transferring the recombinant plasmids to a mutant of $B$. pertussis deficient in haemolysin and adenylate cyclase, a plasmid was identified which restored both these activities.
\end{abstract}

\section{INTRODUCTION}

Bordetella pertussis is a pathogen which is difficult to study in vitro because of its sensitivity to inhibitory substances in conventional media (Parker, 1976), and its tendency to undergo antigenic variation with continual subculture (Leslie \& Gardner, 1931). Several virulencerelated components have been described: these include pertussis toxin (or pertussigen), heatlabile toxin (HLT) (Wardlaw \& Parton, 1983), an adenylate cyclase toxin (Hewlett et al., 1985), filamentous haemagglutinin (FHA) (Sato et al., 1979), two major cell-envelope polypeptides of $M_{\mathrm{r}} 28000$ and 30000 (Wardlaw \& Parton, 1979) and cell-surface heat-labile agglutinogens (Preston, 1976). There has been a great deal of recent interest in these factors with a view to developing a defined acellular vaccine with greater efficacy and lower toxicity than the present whole-cell vaccine (Robinson et al., 1985). However, little still is known of the role of these components in the pathogenesis of pertussis.

The advent of recombinant DNA technology has facilitated the study of pathogens which are difficult to grow and manipulate in the laboratory. However, initial attempts by Weiss \& Falkow (1983) and Dr C. Duggelby (personal communication) to identify $B$. pertussis virulence determinants in gene libraries of the pathogen in Escherichia coli were unsuccessful. This may have been due to the apparent requirement for a trans-acting regulatory factor, identified by transposon mutagenesis (Weiss et al., 1983), for the expression of several virulence determinants in B. pertussis. However, Shareck \& Cameron (1984) reported the cloning and expression of the two virulence-associated cell-envelope polypeptides of $B$. pertussis in $E$. coli. These workers suggested that they may have cloned the trans-acting regulatory factor on the same insert.

Abbreviations: TE, Tris/HCl-EDTA buffer; HLT, heat-labile toxin; FHA, filamentous haemagglutinin; AS, anthranilate synthase; GS, glutamine synthetase. 
We have constructed a gene library of $B$. pertussis in a broad-host-range cosmid vector, pLAFR 1 , with the rationale that if expression of $B$. pertussis virulence determinants in $E$. coli was not obtained, the gene library could be transferred to a suitable Bordetella host. The cosmid, pLAFR1, is a derivative of the broad-host-range vector pRK290 (Friedman et al., 1982). Like pRK290, pLAFR1 is not self-transmissible, but can be conjugated into Gram-negative recipients in the presence of a helper plasmid, such as pRK2013, which contains the RK2 tra genes. Here we report the complementation of $E$. coli auxotrophs by our gene library. Although we were unable to detect expression of several $B$. pertussis virulence determinants in $E$. coli, a clone was identified which complemented adenylate cyclase and haemolysin-deficient mutants of $B$. pertussis.

\section{METHODS}

Bacterial strains and media. The bacteria used are listed in Table 1. E. coli strains were grown with shaking in nutrient broth (Oxoid). The solid and liquid minimal medium used, except where otherwise stated, was that described by Clowes \& Hayes (1968). Depending on the phenotype of the strain, minimal medium was supplemented with amino acids at $20 \mu \mathrm{g} \mathrm{ml}^{-1}$ (final concentration) and thiamin at $2 \mu \mathrm{g} \mathrm{ml}^{-1}$ (final concentration). Other media used were M9 minimal medium (Maniatis et al., 1982) and CL medium (Imaizumi et al., 1983). B. pertussis was grown on Bordet-Gengou (BG) medium (Gibco-BRL) containing $20 \%(\mathrm{v} / \mathrm{v})$ defibrinated horse blood (Gibco-BRL) for $72 \mathrm{~h}$ at $35^{\circ} \mathrm{C}$ in a moist atmosphere. A loopful of these cultures was used to inoculate $50 \mathrm{ml}$ of a defined (Stainer and Scholte) medium (Stainer \& Scholte, 1971) in $250 \mathrm{ml}$ flasks. The flasks were incubated in an orbital incubator at 80 r.p.m. at $37^{\circ} \mathrm{C}$. For selective and maintenance purposes, antibiotics (Sigma) were present in media at the following final concentrations: tetracycline, $10 \mu \mathrm{g} \mathrm{ml}^{-1}$; streptomycin, $200 \mu \mathrm{g} \mathrm{ml}^{-1}$; and kanamycin, $20 \mu \mathrm{g} \mathrm{ml}{ }^{-1}$.

Isolation of DNA. Plasmid DNA was isolated by the method of Birnboim \& Doly (1979). Plasmid for the construction of the gene library was further purified by centrifugation to equilibrium in a caesium chlorideethidium bromide gradient as described by Maniatis et al. (1982). B. pertussis chromosomal DNA was prepared by a method based on that of Hull et al. (1981). Briefly, a $50 \mathrm{ml}$ culture grown for $48 \mathrm{~h}$ was harvested by centrifugation and washed once in $1 \mathrm{~mm}$-EDTA, $10 \mathrm{~mm}$-Tris/ $\mathrm{HCl}, \mathrm{pH} 8.0$ (TE) with $100 \mathrm{~mm}-\mathrm{NaCl}$. Washed cells were resuspended in $20 \mathrm{ml} 25 \%$ (w/v) sucrose in $50 \mathrm{~mm}$-Tris/HCl, $1 \mathrm{~mm}$-EDTA pH 8.0 on ice. Lysozyme (Sigma) was added ( $50 \mu \mathrm{l} 40 \mathrm{mg}$ lysozyme $\mathrm{ml}^{-1}$ in TE). After $5 \mathrm{~min}$ at room temperature, $10 \mu \mathrm{l}$ proteinase $\mathrm{K}$ (Gibco-BRL) (20 $\left.\mathrm{mg} \mathrm{ml}^{-1}\right), 100 \mu \mathrm{l} \mathrm{RNase} \mathrm{A}$ (Sigma) $\left(10 \mathrm{mg} \mathrm{ml}^{-1}\right.$ heated before use at $100^{\circ} \mathrm{C}$ for $15 \mathrm{~min}$ ) and $400 \mu \mathrm{l} 0.5 \mathrm{M}$-EDTA were added. Cells were lysed by the addition of $250 \mu \mathrm{l} 10 \%(\mathrm{w} / \mathrm{v})$ sodium $N$-lauroylsarcosinate, and were allowed to rest on ice until lysis was complete. The lysate was incubated at $42{ }^{\circ} \mathrm{C}$ for $60 \mathrm{~min}$ and extracted three times with equal volumes of $1: 1(\mathrm{v} / \mathrm{v})$ phenol (TE-saturated)/chloroform followed by one extraction with chloroform alone. To the aqueous layers, $1 / 10$ vol. $3 \mathrm{M}$-sodium acetate was added followed by 2 vols ethanol. The precipitated DNA was wound off and slowly dissolved in $1.5 \mathrm{ml} \mathrm{TE}$, and dialysed at $4{ }^{\circ} \mathrm{C}$ in the same buffer with three changes over $3 \mathrm{~d}$.

Construction of the gene library. Ligations, digestions with restriction enzymes and treatment with alkaline phosphatase were done according to the manufacturer's instructions. B. pertussis DNA was partially digested for $1 \mathrm{~h}$ with EcoRI (Gibco-BRL) using a doubling dilution series of the enzyme. Digestions were terminated by adding EDTA to a final concentration of $20 \mathrm{mM}$ and heating to $68^{\circ} \mathrm{C}$ for $10 \mathrm{~min}$. Those digests which generated fragment lengths of $15-50 \mathrm{~kb}$ (determined by electrophoresis on a $0.3 \%$, w/v, agarose gel) were pooled, and loaded onto a 20 $40 \%(\mathrm{w} / \mathrm{v})$ sucrose gradient in $1 \mathrm{M}-\mathrm{NaCl}, 20 \mathrm{mM}-\mathrm{Tris} / \mathrm{HCl}, 5 \mathrm{mM}-\mathrm{EDTA}, \mathrm{pH} 8 \cdot 0$. After centrifugation at $50000 \mathrm{~g}$ at $20^{\circ} \mathrm{C}$ for $24 \mathrm{~h}$, fractions were collected and those with fragments in the $20-35 \mathrm{~kb}$ region were pooled and dialysed extensively in TE. The cosmid LAFR1 (21.6 kb) was completely digested with EcoRI (pLAFR1 has a unique EcoRI site), and then treated with calf intestinal alkaline phosphatase (Boehringer-Mannheim). Chromosomal DNA and pLAFR 1 were ligated, with cosmid present in a fivefold higher molar concentration, using Ligaid (P \& S Biochemicals Ltd, Liverpool, UK), and packaged in vitro as described by Maniatis et al. (1982). E. coli DH1 was infected with the packaged DNA as reported by Ish-Horowicz \& Burke (1981). Tetracycline-resistant coloniès (pLAFRI confers tetracycline resistance) were picked and subcultured in nutrient broth and stored at $-20^{\circ} \mathrm{C}$ with an equal volume of glycerol.

Nick-translation and hybridization. The method of Rigby et al. (1977) was used to nick-translate B. pertussis DNA. Plasmid preparations from recombinant clones were spotted onto nitrocellulose and allowed to hybridize with ${ }^{32} \mathrm{P}$-labelled $B$. pertussis DNA according to a procedure described by Maniatis et al. (1982).

Gel electrophoresis. DNA molecules were separated on $0.7 \%$ or $0.3 \%(\mathrm{w} / \mathrm{v})$ agarose (Sigma type I or Seakem HGT) gels in a running buffer containing $90 \mathrm{mM}$-Tris base, $90 \mathrm{~mm}$-boric acid, $1 \mathrm{~mm}$-EDTA, pH 8.3. $M_{\mathrm{r}}$ values were estimated by comparison with an EcoRI digest of $\lambda$ DNA.

Mating methods. For E. coli to E. coli conjugation experiments, overnight cultures of the recipient, the donor and the 'helper strain' [HB101(pRK2013)] were mixed together in equal volumes, spread on nutrient agar plates and 
Table 1. Strains of E. coli and B. pertussis

Strain

E. coli $\mathrm{DH} 1$

E. coli $\mathrm{HB} 101$

E. coli HB101(pLAFR1)

E. coli $\mathrm{HB} 101$ (pRK 2013)

E. coli $\mathrm{JC} 3272$

E. coli Th16*

E. coli $\mathrm{YMCl1}^{*}$

E. coli $\mathrm{P}^{2} 78 \mathrm{~F}^{-}$

E. coli $\mathrm{KF} 51^{*}$

E. coli $\mathrm{KF} 52^{*}$

E. coli KF54*

E. coli NCIB 10766*

E. coli NCIB 10767*

E. coli CA8306*

B. pertussis TAB I

B. pertussis 347

B. pertussis 348

B. pertussis 349
Genotype/properties

recAl endAI gyrA96 $\mathrm{Thi}^{-}$hsdRl7 supE44 hsdS20 recA $13 \mathrm{Ara}^{-}$proA 2 lac Y1 galK 2 rpsL20 Xyl Mlt ${ }^{-} \sup E 44$

Lys $^{-} \mathrm{Trp}^{-} \mathrm{His}^{-} \mathrm{Strp}^{\mathrm{r}}$

Thi endA hsr lacU169 glnA : :Tn5 (contains $K$. aerogenes Hut operon with hutC)

Thi- endA hsr lacU169 $\Delta g \ln G$-glnA (contains $K$. aerogenes Hut operon with hutC)

$\mathrm{Thr}^{-} \mathrm{Leu}^{-} \mathrm{Thi}^{-} \mathrm{Lac}^{-}$Strp ${ }^{r}$

$\operatorname{trp} E$

$\operatorname{trpA}$

$\operatorname{trp} B$

$\operatorname{trpC}$

$\operatorname{trp} D$

$\triangle c y a \mathrm{Thi}^{-}$

A Tn5 mutant deficient in FHA, adenylate cyclase, haemolysin, HLT and pertussis toxin A tn5 mutant deficient in haemolysin and adenylate cyclase

A $\operatorname{Tn} 5$ mutant deficient in haemolysin
Source or reference

Maniatis et al. (1982)

Friedman et al. (1982)

Achtman et al. (1971)

Dr B. Magasanik, Massachusetts Institute of

Technology, Cambridge, Massachusetts, USA

Clowes \& Hayes (1968)

NCIB, Torry Research

Station, Aberdeen, UK

Kiely \& O’Gara (1983)

Brownlie et al. (1985)

Weiss et al. (1983)

* Spontaneous streptomycin resistant mutants were isolated from these strains and used in conjugation experiments.

incubated overnight at $37^{\circ} \mathrm{C}$. Subsequent growth was diluted in saline $(0.85 \% \mathrm{NaCl})$, and dilutions were plated onto appropriate selective medium. When individual clones were screened for their ability to complement auxotrophs, static overnight cultures in nutrient broth of the recipient and HB101(pRK2013) were mixed together in equal volumes and added (an equal volume) to the clones grown overnight in wells of microtitre plates containing nutrient broth. After mixing, a sample from each well was spotted onto nutrient agar and incubated overnight at $37^{\circ} \mathrm{C}$. Growth from these plates was subsequently spotted onto selective minimal medium. The selective medium contained tetracycline and streptomycin for selection of the plasmid and recipient respectively; for selection of plasmid which would complement the auxotrophic marker of the recipient, the appropriate amino acid was not included in the minimal medium. For $E$. coli to $B$. pertussis conjugation experiments, the same procedure was followed except that $B$. pertussis was grown in Stainer and Scholte medium before mixing with $E$. coli. Mixtures were spotted onto BG plates, and the subsequent growth was transferred to selective BG plates containing tetracycline, kanamycin (the $B$. pertussis recipients used were resistant to kanamycin) and $5 \times 10^{7}$ p.f.u. Tl phage $\mathrm{ml}^{-1}$ (as an added selection against E. coli)

Screening procedures for B. pertussis virulence determinants. FHA was screened for by an enzyme-linked immunosorbent assay. Briefly, colonies were grown on CL plates overnight and transferred to prewetted nitrocellulose filters (Schleicher and Schuell; BA85, $0.45 \mu \mathrm{m}$ ). Filters were placed above a dish of chloroform for 10 min, to lyse the cells, and incubated overnight at $4{ }^{\circ} \mathrm{C}$ in $5 \%(\mathrm{w} / \mathrm{v}) \mathrm{BSA}$ in PBS $\left(8.0 \mathrm{~g} \mathrm{NaCl}^{-1}, 0.2 \mathrm{~g} \mathrm{KCl}^{-1}\right.$, $\left.1 \cdot 15 \mathrm{~g} \mathrm{Na}_{2} \mathrm{HPO}_{4} 1^{-1}, 0.2 \mathrm{~g} \mathrm{KH}_{2} \mathrm{PO}_{4} 1^{-1}\right)$. After three 15 min washes in PBS, the filters were incubated with a $1 / 10$ dilution (in PBS with $1 \%, \mathrm{w} / \mathrm{v}, \mathrm{BSA}$ ) of a cocktail of mouse monoclonal anti-FHA antisera (kindly supplied by Dr L. A. E. Ashworth, PHLS Centre for Applied Microbiology and Research, Porton Down, UK) with gentle shaking for $2 \mathrm{~h}$ at room temperature. The filters were washed as before and incubated with a $1 / 3000$ dilution (in PBS with $1 \%, w / v, B S A$ ) of anti-mouse IgG horse-radish peroxidase enzyme conjugate (Scottish Antibody Production Unit, Law Hospital, Carluke, UK) with gentle shaking for $2 \mathrm{~h}$ at room temperature. After washing the filters three times as before, the filters were incubated with substrate $\left[2 \mathrm{mg} \mathrm{3-amino-9-ethylcarbazole} \mathrm{ml}^{-1}\right.$ (Sigma), $0.024 \%, \mathrm{v} / \mathrm{v}, \mathrm{H}_{2} \mathrm{O}_{2}$ in $50 \mathrm{mM}$-sodium acetate, $\left.\mathrm{pH} 5.0\right]$. The reaction was terminated after $30 \mathrm{~min}$ by placing the filters in distilled water.

The cell-envelope polypeptide of $M_{\mathrm{r}} 30000$ was screened for by the same procedure except that a $1 / 100$ dilution of mouse monoclonal antiserum specific to this polypeptide (kindly supplied by $\operatorname{Dr} \mathbf{J}$. B. Hertz, Department of Clinical Microbiology, Hvidovre Hospital, Copenhagen, Denmark) was used in place of anti-FHA. 
To screen for HLT, clones were grown overnight in CL medium in wells of microtitre plates and injected subcutaneously into three-week-old mice [four cultures $(50 \mu \mathrm{l} \mathrm{each})$ per mouse]. Mice were examined the next day for a haemorrhagic reaction (Parton, 1986).

Haemolytic activity was screened for by spotting clones onto BG sandwich plates. Grown cells were lysed either by leaving the plates at room temperature for $5 \mathrm{~d}$ or by treatment with chloroform vapour for $10 \mathrm{~min}$. After $24 \mathrm{~h}$ incubation, both at room temperature and at $4^{\circ} \mathrm{C}$, clones were examined for a zone of haemolysis.

To screen for adenylate cyclase, the recombinant plasmids were transferred from $E$. coli $\mathrm{DH} 1$ to $E$. coli CA8306 $(\triangle c y a)$ using the method described above. Complementation of the cya mutation was screened for by selection on minimal medium plates with tetracycline, streptomycin and with the glucose replaced by either lactose or maltose.

Enzyme assays. Bacteria were grown to mid-exponential phase in litre volumes in minimal medium for $E$. coli strains, or Stainer and Scholte medium for $B$. pertussis strains. Cells were harvested by centrifugation, washed once in $50 \mathrm{~mm}$-potassium phosphate, $1 \mathrm{~mm}-\beta$-mercaptoethanol, $\mathrm{pH} 7.5$, resuspended in about $2.0 \mathrm{ml}$ of the same buffer and disrupted using an MSE ultrasonic disintegrator for three $40 \mathrm{~s}$ intervals with intervening cooling. Debris was removed by centrifugation at $20000 \mathrm{~g}$ for $30 \mathrm{~min}$ at $4^{\circ} \mathrm{C}$. Supernates were assayed for anthranilate synthase (AS) activity, histidase activity, glutamine synthetase (GS) activity (using the $\gamma$-glutamyltransferase assay) and adenylate cyclase activity by the methods described by Baskerville \& Twarog (1972), Coote (1974), Bender $e t$ al. (1977) and Brownlie et al. (1985), respectively. Protein was estimated by the method of Herbert et al. (1969) with BSA as standard.

\section{RESULTS AND DISCUSSION}

\section{Construction of gene library of $B$. pertussis}

The gene library of $B$. pertussis was constructed in the cosmid vector pLAFR 1 as described in Methods. The efficiency of the procedure was about 20000 tetracycline resistant colonies per $\mu \mathrm{g}$ of $B$. pertussis DNA packaged. From ten clones, the average insert size was calculated to be $24.9 \mathrm{~kb}$ (SD 4.35). Hybridization studies with plasmid preparations and nick-translated ${ }^{32} \mathrm{P}$ labelled $B$. pertussis DNA confirmed that the insert, for the ten clones, was $B$. pertussis DNA (no hybridization was observed for pLAFR1 without insert). We subcultured 500 tetracyclineresistant recombinants and stored these frozen with added glycerol. From the equation derived by Clarke \& Carbon (1976) and assuming $B$. pertussis to have a genome of similar size to that of E. coli $(4100 \mathrm{~kb})$, the gene library was calculated to be $>95 \%$ complete.

\section{Complementation of $E$. coli auxotrophs}

To determine whether the reported inability of $E$. coli to express $B$. pertussis DNA was a general phenomenon or confined to virulence determinants, the gene library was tested for its ability to relieve auxotrophic phenotypes in $E$. coli. Initially, the gene library was pooled into groups of 50 clones for convenience and these were conjugated en masse into the $E$. coli strain JC3272 ( His $^{-} \mathrm{Trp}^{-} \mathrm{Lys}^{-}$). Three of the clone pools complemented the Trp- phenotype but none complemented the His ${ }^{-}$phenotype (a high reversion rate of the recipient to $\mathrm{Lys}^{+}$made this an unsuitable marker to score for complementation). For each of these three pools, the rate of Trpcomplementation was roughly $1 / 50$ the rate of transfer of recombinant pLAFR1 (i.e. the rate of tetracycline resistance transfer). Although this suggested that one clone, out of the 50 in each pool, was responsible for the observed complementation, it was possible that the clones were not all growing at the same rate, and that some may have been diluted out of recognition. Therefore, subsequent crosses were done using clones individually grown in microtitre plates.

Using this method, four clones (strain DH1 with either pLAFR1018, pLAFR1252, pLAFR1390 or pLAFR1397) were identified which complemented the trpE mutation of $E$. coli KF51. However, none were identified which complemented the $\operatorname{trp} A, \operatorname{trp} B, \operatorname{trp} C$ or $\operatorname{trp} D$ mutations of $E$. coli (strains KF52, KF54, NCIB 10766 and NCIB 10767, respectively). The four clones which complemented trpE could be traced back to the three pools which complemented the $\mathrm{Trp}^{-}$phenotype of strain JC3272 in earlier experiments. As none of these clones complemented any of the other Trp- mutations, strain JC3272 was presumed to be $\operatorname{trpE}$. The reason why only one of the five genes required for tryptophan synthesis in $E$. coli was complemented by the $B$. pertussis gene library is not known. It could be due to physiological incompatibilities between the two organisms, either in the tryptophan synthetic pathway or in the manner in which expression of the responsible genes is regulated. The former seems unlikely 
Table 2. Anthranilate synthase activities in extracts of B. pertussis and E. coli

E. coli strains were grown in minimal medium and $\boldsymbol{B}$. pertussis was grown in Stainer and Scholte medium. Activities are expressed as pmol anthranilate formed (mg protein $)^{-1} \mathrm{~min}^{-1} \pm \mathrm{SD}$. The number of determinations are given in parentheses. Tryptophan, when present in the growth medium, was at a final concentration of $20 \mu \mathrm{g} \mathrm{m} \mathbf{l}^{-1}$.

Bacterial strain

E. coli $\mathrm{DH} 1$

E. coli $\mathrm{JC} 3272$

E. coli JC3272(pLAFR1018)

E. coli JC3272(pLAFR1018)

$B$. pertussis TAB I

B. pertussis TAB I
Tryptophan present

$(+)$ or absent $(-)$ in growth medium

-
+
-
+
+
AS activity

$0.84 \pm 0.26$ (4)

$<0.05 \quad(2)$

$0.84 \pm 0.33(3)$

$0.08 \pm 0.03(3)$

$4.82 \pm 0.22(4)$

$0.54 \pm 0.28(2)$

in that the tryptophan synthetic pathway is unusually well-conserved for the broad range of organisms studied; on the other hand, its genetic organization and regulation is quite diverse (Crawford, 1975). Alternative explanations are that modification of certain regions of $B$. pertussis DNA may occur in E. coli preventing its expression, or simply that the genes are not represented in the library.

Plasmid preparations of the four clones were digested with EcoRI. Two bands of approximately $20 \mathrm{~kb}$ and $2.8 \mathrm{~kb}$ were common to the four clones. Plasmids pLAFR 1018, pLAFR 1252 and pLAFR 1397 had an additional small fragment of about $2.4 \mathrm{~kb}$, and pLAFR 1252 also had a fragment of about $4.5 \mathrm{~kb}$. Plasmid pLAFR1390, on the other hand, had an additional fragment of about $5 \cdot 3 \mathrm{~kb}$. From this it can be concluded that anthranilate synthase, (the product of $\operatorname{tr} E$ ) is encoded somewhere on the two common fragments which are flanked on either side by an $E c o$ RI fragment of $5.3 \mathrm{~kb}$ and two EcoRI fragments of 2.4 and $4.5 \mathrm{~kb}$. That none of these clones complemented $\operatorname{trp} A, \operatorname{trp} B, \operatorname{trp} C$, or $\operatorname{trp} D$ would suggest that the Trp biosynthetic genes of $B$. pertussis are not clustered in a single operon; however, the inability to detect these genes elsewhere in the gene library by complementation does not substantiate this.

Glutamine-dependent AS activity was determined in cell-free extracts of E. coli JC3272 (trpE) harbouring the recombinant plasmid pLAFR 1018 (Table 2), and was compared with that in $E$. coli $\mathrm{DH} 1$ and $B$. pertussis TAB I. When grown in the absence of tryptophan, pLAFR1018 restored AS activity of the $\operatorname{trp} E$ strain to a level comparable to that expressed by $E$. coli $\mathrm{DH} 1$, but not as high as that expressed by $B$. pertussis grown without tryptophan; this would suggest that expression was under the influence of the $E$. coli regulatory machinery. Expression of AS from pLAFR 1018 was repressed about tenfold when the strain was grown in the presence of tryptophan; similarly AS was repressed about tenfold in B. pertussis when grown with tryptophan. Because of the large size of the insert in pLAFR1018, it is not known whether the observed repression is due to the Trp repressor of $E$. coli, or a repressor of B. pertussis. Alternatively, some other mechanism such as attenuation may be involved. Glutaminedependent AS activity, for all organisms studied so far (Crawford, 1975), not only depends on the large $\operatorname{trp} E$ subunit but also on a smaller glutamine amido-transfer subunit which is one of the $\operatorname{trp} D$ products in $E$. coli. Whether or not a $B$. pertussis trp $E$ product is acting in conjunction with an $E$. coli trpD product in $E$. coli JC3272(pLAFR1018) requires further investigation.

Other auxotrophic markers in $E$. coli which were complemented were an undefined $\mathrm{Thr}^{-}$ mutation in $E$. coli $\mathrm{P} 678 \mathrm{~F}^{-}$, by pLAFR1315, and $g \ln A$ (GS) of $E$. coli $\mathrm{TH} 16$ by either pLAFR1132 or pLAFR1109. These were identified by the ability of the strains P678F- and TH16 to grow on minimal medium without threonine and glutamine, respectively. Eco RI digests of plasmid preparations of these clones indicated that the insert consisted of the following fragments (size in kb): pLAFR1315, 10.0, 8.6, 3.0, 2.5 and 2.3; pLAFR1109, 6.7, 4.6, $4 \cdot 0,3 \cdot 8,3.6$ and 3.0 ; pLAFR $1132,6 \cdot 7,4 \cdot 6,4 \cdot 0,3 \cdot 6,3.0$ and $2 \cdot 3$. With the exception of two fragments, the EcoRI digest profiles were the same for pLAFR1109 and pLAFR1132. Both of these plasmids, when transferred to $E$. coli $\mathrm{YMCl1}$, enabled this strain also to grow on minimal medium without glutamine. 
Table 3. Glutamine synthetase activity in extracts of E. coli THI6 and YMC11 with and without pLAFRI109

$E$. coli strains were grown in $\mathrm{M} 9$ medium where the $\mathrm{NH}_{4} \mathrm{Cl}$ was replaced by $15 \mathrm{~mm}$-sodium glutamate together with glutamine at the concentration indicated. GS activity is expressed as $\mu$ mol $\gamma$-glutamyl hydroxamate formed $(\mathrm{mg} \text { protein })^{-1} \mathrm{~min}^{-1}$. Results are the means of three determinations $\pm S D$.

E. coli strain

YMC11*
TH16*
YMC11(pLAFR1109)
YMC11(pLAFR1109)
TH16(pLAFR1109)
TH16(pLAFR1109)

Glutamine concn (mM)

15
15
15
$0 \cdot 15$
15
$0 \cdot 15$

GS activity

$$
\begin{gathered}
<0.001 \\
<0.001 \\
0.37 \pm 0.03 \\
1.68 \pm 0.17 \\
0.38 \pm 0.02 \\
1.84 \pm 0.14
\end{gathered}
$$

* Strains without plasmid did not grow well with $0.15 \mathrm{~mm}$-glutamine.

Table 4. The ability of E. coli strains YMC11 and TH16 with and without pLAFRI109 to grow on minimal medium with various nitrogen sources

\begin{abstract}
Strains were inoculated onto $\mathrm{M} 9$ plates where the $\mathrm{NH}_{4} \mathrm{Cl}$ was replaced by the nitrogen sources indicated. The relative level of growth $(-$, no growth; ++ , moderate growth; ++++ , good growth) was determined after $48 \mathrm{~h}$ incubation at $37^{\circ} \mathrm{C}$.
\end{abstract}

$\begin{array}{lccccc}\text { Strain } & \begin{array}{c}\mathrm{NH}_{4} \mathrm{Cl} \\ (20 \mathrm{mM})\end{array} & \begin{array}{c}\text { Arginine }(10 \mathrm{mM})+ \\ \text { glutamine }(0.5 \mathrm{~mm})\end{array} & \begin{array}{c}\text { Proline }(15 \mathrm{mM})+ \\ \text { glutamine }(0.5 \mathrm{~mm})\end{array} & \begin{array}{c}\text { Glutamine } \\ (15 \mathrm{~mm})\end{array} & \begin{array}{c}\text { Glutamine } \\ (0.5 \mathrm{~mm})\end{array} \\ 1(\Delta g \ln G-g \ln A) & - & - & - & ++++ & - \\ 1(\mathrm{pLAFR} 1109) & ++++ & ++++ & ++++ & ++++ & ++ \\ (\text { glnA::Tn5) } & - & ++ & ++ & ++++ & ++ \\ \text { pLAFR1109) } & ++++ & ++++ & +++ & ++++ & ++\end{array}$

GS activity was assayed in exponential phase $E$. coli $\mathrm{TH} 16, E$. coli $\mathrm{YMC} 11$ and in these two strains harbouring pLAFR1109 (Table 3). Activity could not be detected in either E. coli TH16 or E. coli YMC11, but significant levels were detected in strains harbouring pLAFR1109. Activity was approximately fivefold greater when strains harbouring the plasmid were grown under nitrogen-limiting conditions.

It has previously been shown that in $E$. coli the nitrogen regulatory genes $(g \ln L$ and $g \ln G$, which are closely linked to $g \ln A$ ) control the level of arginine transport activity, the high affinity glutamine transport system and the activation of the Klebsiella Hut operon carried by strains TH16 and YMC11 (Tuli et al., 1982). These functions enable enteric bacteria to utilize alternative nitrogen sources when $\mathrm{NH}_{4}^{+}$concentrations are low (Magasanik, 1982). The presence of analogous nitrogen regulatory genes on pLAFR 1109 was assessed in a similar manner to the way in which these were characterized in cloned $E$. coli DNA (Tuli et al., 1982) and in cloned Thiobacillus ferrooxidans DNA (Barros et al., 1985). E. coli strains were assessed for their ability to grow on M9 medium with various nitrogen sources (Table 4). Strains YMC11 and TH16 were unable to grow with $\mathrm{NH}_{4} \mathrm{Cl}$ as the sole nitrogen source due to lack of GS $(g \ln A)$; when strains harboured pLAFR 1 109, however, they grew well with $\mathrm{NH}_{4} \mathrm{Cl}$ as the sole nitrogen source. Strain YMC11, unlike strain TH16 which contains $g \ln L$ and $g \ln G$ expressed from the $g \ln L$ promoter, was also unable to grow with arginine or proline and limiting glutamine, due to the lack of transport functions dependent on $g \ln L$ and $g \ln G$ activities. The plasmid pLAFR 1109 enabled both strains to grow normally on these media indicating that the cloned $B$. pertussis DNA was able to complement the $g \ln L$ and $g \ln G$ functions in addition to the $g \ln A$ functions of $E$. coli. Consistent with this was the further finding that histidase levels were increased when strain YMC11 (pLAFR1109) was grown under nitrogen-limiting conditions (the Klebsiella Hut operon carried by this strain is hutC and therefore does not require histidine for induction). Cell extracts were prepared after growth of strain YMC11(pLAFR1109) in M9 medium where the $\mathrm{NH}_{4} \mathrm{Cl}$ was replaced by $15 \mathrm{mM}$-sodium glutamate and either $0.15 \mathrm{~mm}$ - or $15 \mathrm{~mm}$-glutamine. Means of 


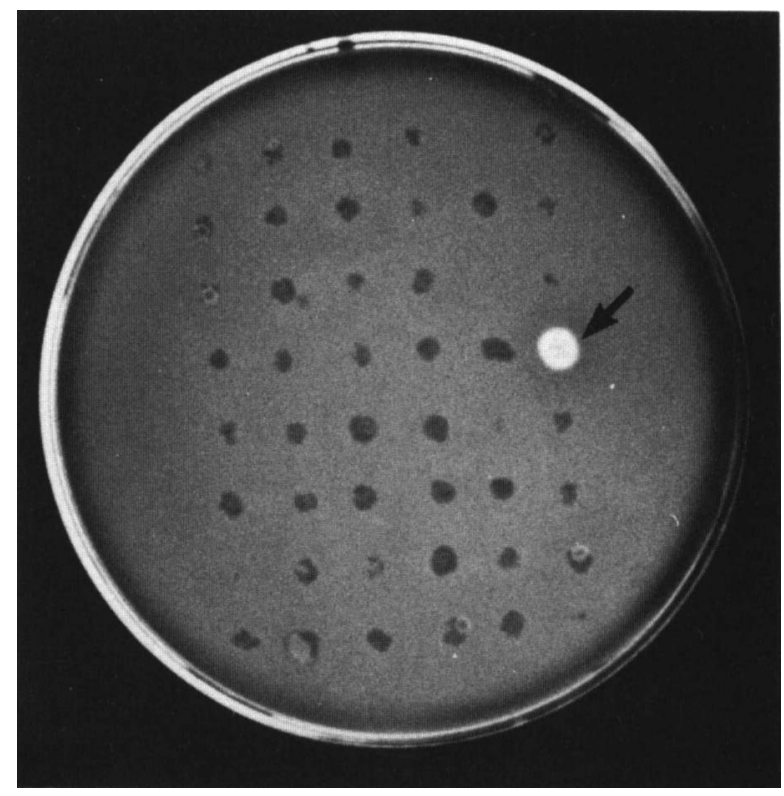

Fig. 1. Complementation of the haemolysin-deficient Tn5 mutant, B. pertussis 348, by pLAFR 1138 . Recombinant plasmids were transferred from $E$. coli DH1 to B. pertussis 348 as described in Methods. The arrow points to $B$. pertussis 348 harbouring pLAFR 1138 .

histidase activities $\left[\mu \mathrm{mol}\right.$ urocanate formed $(\mathrm{mg} \text { protein })^{-1} \min ^{-1} \pm \mathrm{SD}$ ] from three determinations were as follows: $0.17 \pm 0.01$ after growth with $15 \mathrm{~mm}$-glutamine, and $0.27 \pm$ 0.03 after growth with $0.15 \mathrm{~mm}$-glutamine. Strain YMC11 (without plasmid) grew very poorly under these nitrogen-limiting conditions $(0.15 \mathrm{~mm}$-glutamine), but it has previously been demonstrated that histidase levels do not increase when strain YMC11 and other $\operatorname{gln} G g \ln L$ strains are grown under the same nitrogen-limiting conditions (Tuli et al., 1982; Barros et al., 1985 ). These results suggest that $B$. pertussis GS itself, or other associated functions (within $25 \mathrm{~kb}$ ), have the potential to regulate nitrogen acquisition in a manner similar to that in the enteric bacteria.

Other auxotrophic markers in $E$. coli which the gene library did not complement were proA2 of strain $\mathrm{HB} 101$ and an undefined Leu- mutation of strain $\mathrm{P}^{-} 78 \mathrm{~F}^{-}$. This may be for the reasons discussed above. The findings of this report, however, do indicate that it is possible to get expression of $B$. pertussis physiological functions in $E$. coli.

\section{Screening for B. pertussis virulence determinants}

The $500 \mathrm{E}$. coli clones were screened for expression of FHA, HLT, adenylate cyclase, haemolysin and the cell-envelope polypeptide of $M_{\mathrm{r}} 30000$ as described in Methods. Expression of these virulence determinants was not detected in the gene library in $E$. coli. These virulence determinants are lost concomitantly when $B$. pertussis is grown in medium where the $\mathrm{NaCl}$ is replaced by one of several salts or organic acids suggesting a common regulatory mechanism (Brownlie et al., 1985). Weiss et al. (1983) isolated a single transposon insertion mutant of $B$. pertussis (strain 347 ) which lacked several virulence determinants. These workers suggested that a trans-acting function, which is required for expression of virulence determinants, was inactivated by transposon insertion in $B$. pertussis 347 . A regulatory model was proposed (Weiss $\&$ Falkow, 1984) whereby expression of virulence factors is governed by the putative transacting factor in response to external stimuli. The observed lack of expression of $B$. pertussis virulence determinants in gene libraries, with $E$. coli as the host, is consistent with the proposed requirement for an additional $B$. pertussis function for expression of these determinants. 
Recombinant plasmids were transferred from $E$. coli $\mathrm{DH} 1$ to $B$. pertussis 348 [a transposon mutant deficient in haemolysin and adenylate cyclase (Weiss et al., 1983)] as described in Methods. A recombinant plasmid (pLAFR1138) was identified which complemented both the haemolytic activity (Fig. 1) and adenylate cyclase activity (results not shown) of B. pertussis 348 . This same plasmid also restored the haemolytic activity of B. pertussis 349 (a transposon mutant deficient in haemolysin alone). This result supports the suggestion that the haemolysin and adenylate cyclase are closely linked, perhaps on the same operon (Weiss et al., 1983). However, the haemolytic activity conferred by pLAFR 1138 was not expressed when the plasmid was transferred to $B$. pertussis 347 , confirming the requirement for a trans-acting factor for expression of haemolysin. Furthermore, no haemolytic activity or calmodulin-responsive adenylate cyclase activity was detected (results not shown) in $E$. coli DH1 harbouring pLAFR1138 [ $B$. pertussis adenylate cyclase is unusual in its marked responsiveness to stimulation by calmodulin (Hewlett et al., 1985)].

Future work will be aimed at subcloning and characterizing the adenylate cyclase and haemolysin determinants with a view to determining their role in pathogenesis.

We are grateful to Drs A. M. Friedman, B. Kiely, B. Magasanik and A. Weiss for kindly supplying strains of $E$. coli and B. pertussis, Drs L. A. E. Ashworth and J. B. Hertz for monoclonal antiserum and Mr M. Achison and Mrs E. Berry for technical assistance. This work was funded by the Medical Research Council, grant number G8307878CB. Equipment was made available by the Wood Boyd fund of the University of Glasgow Medical Research Fund.

\section{REFERENCES}

Achtman, M., Willetts, N. \& Clark, A. J. (1971). Beginning a genetic analysis of conjugational transfer determined by the $\mathrm{F}$ factor in Escherichia coli by isolation and characterization of transfer-deficient mutants. Journal of Bacteriology 106, 529-538.

Barros, M. E. C., Rawlings, D. E. \& Woods, D. R. (1985). Cloning and expression of the Thiobacillus ferrooxidans glutamine synthetase gene in Escherichia coli. Journal of Bacteriology 164, 1386-1389.

BASKer ville, E. N. \& TWAROG, R. (1972). Regulation of the tryptophan synthetic enzymes in Clostridium butyricum. Journal of Bacteriology 112, 304-314.

Bender, R. A., Janssen, K. A., Resnick, A. D., Blumenberg, M., Foor, F. \& Magasanik, B. (1977). Biochemical parameters of glutamine synthetase from Klebsiella aerogenes. Journal of Bacteriology 129, 1001-1009.

BiRnBoim, H. C. \& Doly, J. (1979). A rapid alkaline extraction procedure for screening recombinant plasmid DNA. Nucleic Acids Research 7, 1513-1523.

Brownlie, R. M., Parton, R. \& Coote, J. G. (1985). The effect of growth conditions on adenylate cyclase activity and virulence-related properties of Bordetella pertussis. Journal of General Microbiology 131, $17-25$.

Clarke, L. \& Carbon, J. (1976). A colony bank containing synthetic ColEl hybrid plasmids representative of the entire E. coli genome. Cell 9, 91-99.

Clowes, R. C. \& Hayes, A. (1968). Experiments in Microbial Genetics. Oxford: Blackwell Scientific Publications.

Coote, J. G. (1974). Comparative studies on induction of sporulation and synthesis of inducible enzymes in Bacillus subtilis. Journal of Bacteriology 120, 11021108.

Crawford, I. P. (1975). Gene rearrangements in the evolution of the tryptophan synthetic pathway. Bacteriological Reviews 39, 87-120.
Friedman, A. M., Long, S. R., Brown, S. E., Buikema, W. J. \& Ausubel, F. M. (1982). Construction of a broad host range cosmid cloning vector and its use in the genetic analysis of Rhizobium mutants. Gene 18, 289-296.

Hewlett, E. L., Weiss, A. A., Pearson, R. D., Myers, G. A. \& Cronin, M. J. (1985). Bordetella adenylate cyclase toxin: its intoxication of mammalian cells and effects on cell function. In Pertussis Toxin, pp. 241-250. Edited by R. D. Sekura, J. Moss \& M. Vaughan. London: Academic Press.

Herbert, D., Phipps, P. J. \& Strange, R. E. (1969). Chemical analysis of microbial cells. Methods in Microbiology 5B, 209-344.

Hull, R. A., Gill, R. E., Hsu, P., Minshew, B. H. \& FALKow, S. (1981). Construction and expressions of recombinant plasmids encoding Type 1 or Dmannose-resistant pili from a urinary tract infection Escherichia coli isolate. Infection and Immunity 33, 933-938.

Imaizumi, A., Suzuki, Y., ONo, S., SATo, H. \& SATo, Y. (1983). Heptakis(2,6-O-dimethyl) $\beta$-cyclodextrin: a novel growth stimulant for Bordetella pertussis phase I. Journal of Clinical Microbiology 17, 781-786.

IsH-HoRowicz, D. \& BURKE, J. F. (1981). Rapid and efficient cosmid cloning. Nucleic Acids Research 9, 2989-2998.

KIELY, B. \& O'GARA, F. (1983). Cyclic 3',5'-adenosine monophosphate synthesis in Rhizobium: identification of a cloned sequence from Rhizobium meliloti coding for adenyl cyclase. Molecular and General Genetics 192, 230-234.

LESLIE, P. H. \& GARDNER, A. D. (1931). The phases of Haemophilus pertussis. Journal of Hygiene 31, 423434.

MagasaniK, B. (1982). Genetic control of nitrogen assimilation in bacteria. Annual Review of Genetics 16, 135-168. 
Maniatis, T., Fritsch, E. F. \& SambrooK, J. (1982). Molecular Cloning: A Laboratory Manual. Cold Spring Harbor, New York: Cold Spring Harbor Laboratory.

PARKER, C. (1976). Role of the genetics and physiology of Bordetella pertussis in the production of vaccine and the study of host-parasite relationships in pertussis. Advances in Applied Microbiology 20, 2742.

Parton, R. (1986). Effect of anti-inflammatory agents on the haemorrhagic response of mouse skin to Bordetella pertussis heat-labile toxin. Journal of Medical Microbiology 21, 265-270.

PRESTON, N. W. (1976). Prevalent serotypes of Bordetella pertussis in non-vaccinated communities. Journal of Hygiene 77, 85-91.

Rigby, P. W. J., Dieckmann, M., Rhodes, C. \& Berg, P. (1977). Labelling deoxyribonucleic acid to high specific activity in vitro by nick translation with DNA polymerase I. Journal of Molecular Biology 113, 237-251.

Robinson, A., Irons, L. I. \& Ashworth, L. A. E. (1985). Pertussis vaccine: present status and future prospects. Vaccine 3, 11-22.

SaTo, Y., IzUmiYa, K., Oda, M. A. \& Sato, H. (1979). Biological significance of Bordetella pertussis fimbriae or hemagglutinin for pathogenesis and antibacterial immunity. In International Symposium on Pertussis, pp. 51-57. Edited by C. R. Manclark \& J. C. Hill. Washington, DC: DHEW Publication no. (NIH) 79-1830.

Shareck, F. \& Cameron, J. (1984). Cloning of
Bordetella pertussis outer membrane proteins in Escherichia coli. Journal of Bacteriology 159, 780-782. Stainer, D. W. \& Scholte, M. J. (1971). A simple chemically defined medium for the production of Phase I Bordetella pertussis. Journal of General Microbiology 63, 211-220.

Tuli, R., Fisher, R. \& Haselkorn, R. (1982). The ntr genes of Escherichia coli activate the hut and nif operons of Klebsiella pneumoniae. Gene 19, 109-116.

Wardlaw, A. C. \& Parton, R. (1979). Changes in envelope proteins and correlation with biological activities in B. pertussis. In International Symposium on Pertussis, pp. 94-98. Edited by C. R. Manclark \& J. C. Hill. Washington, DC: DHEW Publication no. (NIH) 79-1830.

Wardlaw, A. C. \& Parton, R. (1983). Bordetella pertussis toxins. Pharmacology and Therapeutics 19, $1-53$.

Weiss, A. A., Hewlett, E. L., Myers, G. A. \& FALKow, S. (1983). Tn5-Induced mutations affecting virulence factors of Bordetella pertussis. Infection and Immunity 42, 33-41.

Weiss, A. A. \& Falkow, S. (1983). The use of molecular techniques to study microbial determinants of pathogenicity. In The Determinants of Bacterial and Viral Pathogenicity, pp. 155-162. Edited by H. Smith, J. P. Arbuthnott \& C. A. Mims. Cambridge: The London Royal Society.

WEISS, A. A. \& FALKOW, S. (1984). Genetic analysis of phase change in Bordetella pertussis. Infection and Immunity 43, 263-269. 